\title{
ASPM Gene
}

National Cancer Institute

\section{Source}

National Cancer Institute. ASPM Gene. NCI Thesaurus. Code C118989.

This gene plays a role in mitotic spindle regulation. 